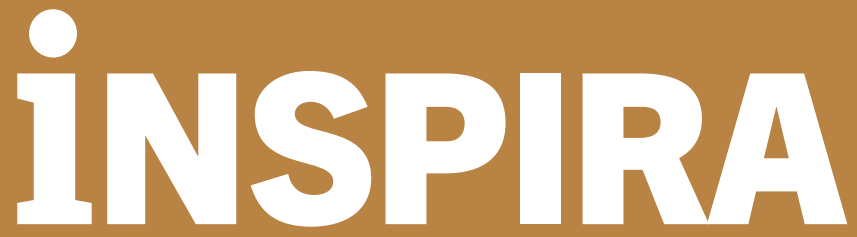

Tidsskrift for anestesi-, operasjon- og intensivsykepleiere

Forskningsartikler | Vol. 16, No. 2, 2021, s. 1-19

\title{
Etniske ulikheter i håndteringen av akutte smerter på akuttmottak eller postoperativ avdeling: en systematisk oversikt, med narrativ syntese
}

\section{Thomas Samsonsen}

Intensivsykepleier, Haukeland universitetetssykehus, Norge

E-post: tsamson@online.no

\section{Asgjerd Litleré Moi}

Intensivsykepleier og professor, Høgskulen på Vestlandet, Norge

\section{Michael Mortensen}

Intensivsykepleier og høgskolelektor, Høgskulen på Vestlandet, Norge

\section{Sammendrag}

Bakgrunn: Smerter er et hyppig fenomen i akuttavdelinger og kan ubehandlet føre til stress, søvnmangel og kroniske smertetilstander for pasientene. Sykepleieres smertehåndtering, inkludert observasjoner og tiltak, kompliseres av variasjonen i smerteuttrykk og reaksjoner på behandlingen hos pasientene. Med større etnisk mangfold i norske sykehus, kan kulturelle forskjeller være til hinder for adekvat smertelindring.

Hensikt: Å oppsummere kunnskap om betydningen av etnisitet for smerteopplevelse og smertehåndteringen hos voksne akutt og/eller kritisk syke pasienter.

Metode: Systematisk oversikt med narrativ syntese. Søket ble utført i Embase, Medline, Cochrane og Cinahl. Det ble søkt etter engelske eller norske/danske/svenske artikler publisert mellom 1980-2021 som omhandlet etnisitet og smertehåndtering i akutt-, postoperative- eller intensivavdelinger på sykehus. Det ble utført en blindet screening av artiklene i henhold til inklusjons- og eksklusjonskriterier. Critical Appraisal Skills Programme (CASP) ble brukt for å kvalitetsvurdere inkluderte studier.

Resultater: Av i alt 1605 studier ble 22 studier inkludert. Studiene omhandlet pasientgrupper på akuttmottak eller postoperativ avdeling. Hyppigst forekom studier av etniske- og raseforskjeller av smerter etter benbrudd, etterfulgt av studier av etniske- og raseforskjeller ved forskjellige akutte smerter; dislokasjon av ledd, akutt koronarsyndrom, traume, magesmerter og postoperative smerter. De fleste studiene (16 av 22) rapporterte etniske forskjeller enten i smerteintensitet og/eller valg av analgetika, dose og/eller ventetid for analgetika. 
Konklusjon: Basert på funnene i denne systematiske oversikten har etnisitet stor betydning for smerteopplevelse og utført smertebehandling på akuttmottak og postoperative avdelinger. Åpenhet for ulike kulturelle smerteuttrykk, samt bevissthet rundt mulige fordommer, er viktig for god smertehåndtering $\mathrm{i}$ akuttavdelinger.

Nøkkelord: akutte smerter; etnisitet; kultur; smertehåndtering; smerteopplevelse; systematisk oversikt

\section{Abstract}

Ethnic differences in the management of acute pain in the emergency department or postoperative care unit: a systematic review, with narrative synthesis

Background: Pain is a common phenomenon in emergency rooms and can untreated lead to stress, lack of sleep, and chronic pain conditions for patients. Nurses' pain management, including observations and measures, is complicated by the variation in pain expression and reactions to pain treatment. With greater ethnic diversity in Norwegian hospitals, cultural differences can be an obstacle to adequate pain relief.

Purpose: To summarize knowledge about the importance of ethnicity for pain experience and pain management in adult acute and/or critically ill patients.

Method: Systematic review with narrative synthesis. The search was performed in Embase, Pubmed, Cochrane, Cinahl, and Google Scholar. A blinded screening for the articles was performed according to the inclusion and exclusion criteria. Critical Appraisal Skills Programme (CASP) was used to assess the quality of the included studies.

Results: A total of 1605 studies was found, of which 22 ended up being included. The studies dealt with patient groups in emergency departments or post-operative wards. Studies of ethnic and racial differences in pain following bone fractures were most frequently reported, followed by studies of ethnic and racial differences in acute pain conditions; joint dislocation, acute coronary syndrome, trauma, abdominal pain, and post-operative pain. Most studies (16 of 22) reported ethnic differences in pain intensity and/or analgesics chosen, dose, and/or waiting time for analgesics.

Conclusion: Based on the findings of this systematic overview, ethnicity significantly influences pain perception and pain management in emergency rooms and post-operative care units. Openness to cultural expressions of pain and awareness of possible prejudices are essential for good pain management in emergency departments.

Keywords: acute pain; culture; ethnicity; pain management; pain perception; systematic review

\section{Introduksjon}

En konsekvens av $\varnothing$ kt etnisk mangfold i Norge betyr at anestesi- og/eller intensivsykepleiere møter pasienter fra ulike kulturer, med ulike behov for smertelindring. Smerter hos andre etniske grupper enn ens egen kan være vanskelig å tolke, og pasienter fra disse gruppene risikerer derfor mangelfull smertelindring (1). Etniske grupper i Norge er en svært heterogen pasientgruppe; det kan være pasienter som har blitt traumatiserte som flyktninger fra samfunn som er forskjellige fra det norske, til arbeidsinnvandrere som kommer fra samfunn der sosiale normer har mange fellestrekk med vårt. Mange har opplevd fengsling og tortur, opphold i flyktningleirer og dramatisk flukt til det nye landet, med tilleggsproblematikk knyttet til tillit, integrering og psykiske traumer.

Feiltolkning av smerter kan medføre under- og overbehandling av smerter som kan få alvorlige konsekvenser for pasienten. Smerter hos akutt og/eller kritisk syke pasienter 
kan virke negativt særlig hos pasienter som er hemodynamisk ustabile og ved respirasjonssvikt eller immunsvikt (2). Smerter forekommer ofte hos akutt- og/eller kritisk syke pasienter, og er et av de mest utfordrende kliniske problemene for anestesi- og intensivsykepleiere (3).

Ifølge Melzack og Katz (2013) er smerte en sensorisk, affektiv og kognitiv opplevelse. Definisjonen er viktig - den sier at smerte og vevsskade kan, men må ikke være samme sak, og at følelser og psykisk tilstand også kan medføre smerter. Kroppen har systemer som kan hemme eller forsterke smerte, der dette blant annet påvirkes av psykiske faktorer (4). Nøyaktige, gyldige og pålitelige målinger av smerte er essensielt for å identifisere faktorer som påvirker smerteintensitet og varighet, og for å bedre diagnostikk og behandling. Vurdering av smerteintensitet inkluderer verbale og numeriske selvrapporteringsverktøy som Numeric Rating Scale (NRS), visuell analog skala (VAS), samt observasjoner av smerteadferd som Critical Care Pain Observation Tool (CPOT) og Behavioral Pain Scale non-intubated (BPS-NI) hos non-verbale pasienter $(2,5)$. Kompleksiteten i smerteuttrykk gjør at disse målingene ikke alltid samsvarer med klinikken. Fordi smerte er et subjektivt fenomen, er pasientens selvrapportering den mest valide målingen av smerteopplevelsen (4).

Smerteopplevelse er opplevelsen pasienten har av smerten. Opplevelse av både smertens intensitet og smertens ubehag er ikke bare en sammensatt prosess som kan leses av amplituden på nociseptive signal. En rekke faktorer påvirker smerteopplevelsen, inkludert forventninger, usikkerhet, multisensoriske input (for eksempel syn, lyd, lukt, smak), adferd, miljø, følelser, motivasjon, selv- versus eksternt påført smerte og ikke minst følelsen av kontroll over situasjonen (6). Smertehåndtering og smertebehandling er ord som går igjen i denne systematiske oversikten fordi de representerer forskjellige tiltak. Ved smertehåndtering gjelder både farmakologiske og ikke-farmakologiske tiltak intensivsykepleier iverksetter for å redusere eller fjerne smertene pasienten opplever (2). Med smertebehandling menes hvilket medikament som velges, opioider eller nonsteroid antiinflammatory drugs (NSAIDS), dose, hyppighet og ventetid for analgetika.

Akutte smerter kjennetegnes ved at de har kort varighet, vanligvis under 3 måneder, og at de reduseres over tid (7). Akutte smerter er et varsel kroppen gir om at noe er galt, og dermed har det en beskyttende funksjon (7). Hvis anestesi- eller intensivsykepleier ikke får kontroll på pasientens smerter i forbindelse med sykdom eller ved kirurgiske inngrep, kan det forårsake skadelige og uønskede virkninger på flere av pasientens organsystem (7). De kliniske konsekvensene kan være lungekomplikasjoner som atelektaser og pneumoni, sirkulatoriske komplikasjoner som takykardi og $\varnothing$ kt behov for oksygen til hjertet, hypertensjon, tromboser og embolier. Det kan forekomme gastrointestinale komplikasjoner som obstipasjon, tarmslyng (ileus), kvalme og brekninger, samt andre komplikasjoner som $\varnothing \mathrm{kt}$ infeksjonsfare, inaktivitet, og redusert søvn (7).

Begrepene rase, etnisitet og kultur brukes ofte synonymt om hverandre i studier, men representerer likevel forskjellige konsepter. Rase brukes til å skille grupper av mennesker i henhold til fysiske egenskaper, biologisk disposisjon eller forfedre (8). Begrepet 
etnisitet fokuserer på skille mellom grupper av mennesker som har felles sosial bakgrunn, atferd, kultur, historie, tro, konvensjoner, tradisjoner og fysiske egenskaper (8). Kultur refererer vanligvis til atferdsmessige og holdningsrelaterte normer, tro, verdier og kunnskap overført og forsterket av medlemmer i gruppen. Kultur former mange aspekter av opplevelsen av smerte, inkludert smerteuttrykk, sosiale roller, forventninger, oppfatninger av det medisinske systemet, når/hvordan/hvor søke helsetjenester, sykdom, tro, atferd, og mottakelighet til medisinske intervensjoner (8). Etnisitet består ikke bare av rase, men refererer også til sosiale, psykologiske og kulturelle egenskaper hos individet. Etnisitet er ifølge Campbell og Edwards (2012) det mest passende begrep i de fleste forskningsstudier på emnet.

Ifølge Narayan (2010) kan pasienter fra andre kulturer enn ens egen uttrykke smerte på andre måter enn de man kjenner til. Barn i noen kulturer lærer å klage og gråte når de har smerter og blir da sett på som flinke (9). Andre kulturer mener at den beste måten å håndtere smerte på er ved å skrike (10). Sykepleiere har, som pasientene også, lært hvordan håndtere smerte. Gjennom sosialiseringsprosess lærer sykepleiere den «normale» eller den «rette» måten å respondere på smerte, og de lærer også den «unormale» eller «gale» måten å håndtere smerte på. Holdninger og adferd som samsvarer med ens egen kultur kan for noen oppfattes som den riktige måten å respondere på smerte, og den som ikke samsvarer er unormal eller feil (9). Når nordmenn møter andre som har sterkere måter å uttrykke smerte på, kjenner mange på usikkerhet. Atferden kommer i konflikt med tradisjonell norsk smerteoppdragelse (1). Ifølge Bjørkli (2019), som er sykehusprest ved sykehuset i Østfold, oppdras barn i Norden til ikke å vise smerte og blir belønnet både verbalt og materielt for å ikke gråte eller vise redsel, for eksempel ved lege- og tannlegebes $\varnothing \mathrm{k}$.

Så vidt vi vet er det mangel på systematiske litteraturstudier som undersøker hvilken betydning etnisitet har for smerteopplevelse og smertehåndtering hos voksne akuttog/eller kritisk syke pasienter. Hensikten med denne studien å oppsummere kunnskap gjennom en systematisk oversikt med narrativ syntese. Studien vil kunne bidra til å $\emptyset \mathrm{ke}$ fokus på eventuelle etniske forskjeller og øke pasientsikkerheten ved å bidra til større åpenhet for etniske ulikheter, og dermed redusere feiltolkning og under- og overbehandling av smerter.

\section{Metode}

Denne systematiske litteraturstudien ble utført i henhold til retningslinjene gitt av Preferred Reporting Items for Systematic Reviews and Meta-Analyses (PRISMA) guidelines (11). Det er søkt etter studier som passer forhåndsdefinerte inklusjonskriterier for å svare på forskningsspørsmål.

\section{Inklusjons- og eksklusjonskriterier}

Inkluderte studier handler om akutte smerter i akuttavdelinger som akuttmottak, postoperativ- og intensivavdeling ettersom dette er avdelinger hvor anestesi- og 
intensivsykepleiere tradisjonelt jobber og hvor de ofte må vurdere og behandle smerter. Kreftsmerter, kroniske smerter, fødselssmerter, smerter hos terminale, smerter hos barn eller psykiatriske pasienter er ekskludert, fordi dette er smerter som kan være komplekse å behandle, i tillegg til at andre faktorer spiller inn på smerteopplevelsen og smertehåndteringen til disse pasientene.

\section{Inklusjons- og eksklusjonskriterier}

Tabell 1 Inklusjons- og eksklusjonskriterier

\begin{tabular}{|c|c|c|c|}
\hline \multicolumn{2}{|c|}{ Inklusjonskriterier } & \multicolumn{2}{|c|}{ Eksklusjonskriterier } \\
\hline 1) & Voksne pasienter $\geq 18$ år & 1) & Studier på barn < 18 år \\
\hline 2) & Akutte smerter & 2) & Kreftsmerter, kroniske smerter, fødselssmerter, \\
\hline 3) & $\begin{array}{l}\text { Evaluering av smerteopplevelse, smerteintensitet } \\
\text { og/eller smertebehandling hos forskjellige }\end{array}$ & & $\begin{array}{l}\text { postpartum-smerter, terminale pasienter, } \\
\text { brystsmerter eller psykiatri }\end{array}$ \\
\hline & etniske grupper / ulike raser & 3) & Utforsker ikke forskjeller på smerteopplevelse/ \\
\hline 4) & $\begin{array}{l}\text { Tilgjengelige full-tekst artikler på engelsk, norsk, } \\
\text { svensk eller dansk }\end{array}$ & & $\begin{array}{l}\text { intensitet eller smertebehandling hos forskjellige } \\
\text { etniske populasjoner }\end{array}$ \\
\hline \multirow[t]{6}{*}{ 5) } & Intensivavdeling, postoperativ avdeling eller & 4) & Ikke tilgjengelig full-tekst \\
\hline & akuttavdelinger på sykehus & 5) & Andre språk enn engelsk, norsk, svensk eller \\
\hline & Originalstudier - kvalitative og kvantitative & & dansk på artiklene \\
\hline & studier & 6) & Andre sykehusavdelinger enn intensiv, \\
\hline & Publisert i perioden 1980-2021 & & postoperativ, akuttavdelinger \\
\hline & & 7) & $\begin{array}{l}\text { Ikke originalartikkel, for eksempel litteraturstudier } \\
\text { eller pågående doktorgradsavhandlinger }\end{array}$ \\
\hline
\end{tabular}

\section{Søkestrategi}

Forskningsspørsmålet ble formulert ved hjelp av population, intervention, comparison, outcome, study design (PICOS) tilnærming. Ettersom tidligere publisert forskning ikke skilte mellom rase og etnisitet, var det nødvendig å søke på både rasemessige og etniske forskjeller til smerteopplevelse og smertehåndtering. I 2019 gjorde vi ett artikkelsøk, de fleste artiklene som er inkludert i denne oversikten er fra artikkelsøket i 2019, men i 2021 gjentok vi artikkelsøket for å se om det var kommet ny forskning på temaet. Denne gangen ble samme søkeord brukt til å søke gjennom de samme databasene som tidligere: Embase, Medline, Cochrane og Cinahl. Etter siste artikkels $\varnothing \mathrm{k}$ i 2021 ble to artikler i tillegg inkludert, se figur 1, PRISMA flytdiagram. Bibliotekar ble brukt ved begge litteraturs $\varnothing \mathrm{k}$ og Rayyan ble brukt som verktøy for å enkelt og raskt gjennomgå artikler på en systematisk måte. Søkestrategien skal være transparent og full søkestreng er vedlagt (vedlegg A).

\section{Studieseleksjon, kvalitetsvurdering og datainnsamling}

Seleksjon av studier bestod av to faser og ble utført av to uavhengige forskere som var blindet for hverandre. Begge har masterutdanning og har en spesialisering i intensivsykepleie. Første og andre screening ble utført ved hjelp av Rayyan (12). I 2019 ble det utført en pilotscreening av de 100 første artikler av totalt 466 artikler for å se hvor samkjørte forskerne var, se figur 1. Deretter ble den første screening utført basert på titler og sammendrag av artiklene som sammensvarte med inklusjons- og eksklusjonskriteriene og duplikater ble fjernet. Hvis en artikkel ikke sammensvarte med inklusjonskriteriene, ble 
den ekskludert. Under den andre screeningen ble gjenværende full-tekst-artikler evaluert en gang til ut ifra inklusjons- og eksklusjonskriterier. I 2021 gjentok forskerne søket, og det ble funnet 1139 artikler. Samme fremgangsmåte for studieseleksjon ble fulgt. Uenigheter ble i andre screeningrunde gjennomgått, en tredje forsker kunne rådføres dersom man ikke nådde konsensus. Studier som er ekskludert etter screeningfasen har blitt ekskludert med begrunnelse (vedlegg B).

Critical appraisal skills programme (CASP) sjekkliste ble brukt til å kritisk vurdere artikler $(13,14)$. Kvaliteten på artiklene ble rangert ut ifra de 11 spørsmålene i CASP, som svak (<25\%), middels (25-50\%), god (50-75\%) eller meget god (75-100\%). Hvis studiens kvalitet var svakere enn $25 \%$ ville den ikke blitt inkludert. Alle inkluderte studier ble bedømt som god eller meget god (tabell 2). Svakhetene til de inkluderte studier omhandler forvekslingsfaktorer (blant annet ikke tatt hensyn til sosioøkonomiske faktorer), måleskjevhet (ulike smertekartleggingsverktøy) og beskrivelse av gruppen (inkluderte pasienters etnisitet). Dette blir drøftet senere i denne artikkelen.

Et forhåndsbestemt datasamlingsskjema ble utarbeidet. Data fra inkluderte studier ble samlet av én person. Følgende data ble registrert: forfatter, årstall, land, utvalg, metode, avdeling, etnisitet, type smerter, smerteintensitet, analgetikum og variabler som kan påvirke utfall som kjønn, alder, språk/morsmål, immigrasjonsbakgrunn, kroppsmasseindeks (KMI), utdanning, helsestatus, angst, depresjon, forsikringsstatus, inntekt, medikamentbruk, røyking osv. Alle disse dataene ble samlet da de kan vise seg å ha en påvirkning på smerteopplevelsen $(4,8)$.

\section{Narrativ analyse}

For å sammenfatte og analysere resultatene fra de inkluderte studiene er det valgt en narrativ syntese. I en narrativ syntese vil leseren få viktig informasjon om studiene som populasjon, studiedesign, kontrollerte variabler, samt styrker og svakheter i studiene (11). Funnene i de 22 studiene er presentert (tabell 2, oversikt over inkluderte studier) og sammenlignet i forhold til smerteintensitet, valg av analgetika, ventetid til analgetika, dose som velges og i hvilken frekvens dosene administreres (tabell 3 , sammenfatning av resultat).

\section{Resultat}

\section{Søkeresultater og studiekarakteristikk}

Totalt ble 602 potensielle studier identifisert gjennom søk i databaser og screening av referanseliste. 22 artikler møtte inklusjonskriteriene og ble inkludert i denne systematiske oversikten (figur 1, PRISMA flowchart). De 22 inkluderte studiene ble publisert mellom 1996 og 2021, hvorav tolv studier før 2010. 16 studier ble utført i USA (15-30), 2 ble utført i Storbritannia (31,32), én studie i Singapore (33), én studie i Kina (34), én studie i Malaysia (35) og én studie i Tyskland (36). Tre av studiene ble utført på postoperativ avdeling $(19,31,37)$. Resten av studiene ble utført på akuttmottak. Totalt ble pasienter fra ti ulike etnisiteter inkludert i studiene. Studiene sammenligner malaysiere 
med kinesere og indere, hvite briter sammenlignet med asiater, afroamerikanere sammenlignet med hvite amerikanere og latinamerikanere, tyskere sammenlignet med tyrkere. Alle de inkluderte studiene er enten prospektive kohortstudier eller retrospektive kasuskontrollstudier.

Flere av studiene som er med i denne systematiske oversikten studerer etniske- og raseforskjeller ved benbrudd på amerikanske akuttmottak. De andre studiene studerer etniske- og raseforskjeller ved forskjellige akutte smerter: dislokasjon av ledd, akutt koronarsyndrom, traume, magesmerter og postoperative smerter. Alle studiene som målte smerteintensitet, brukte enten Numeric Rating Scale (NRS) eller visuell analog skala (VAS). For oversikt over inkluderte studier, se tabell 2, og for sammenfatning av resultater for inkluderte studier, se tabell 3.

\section{PRISMA flytdiagram}
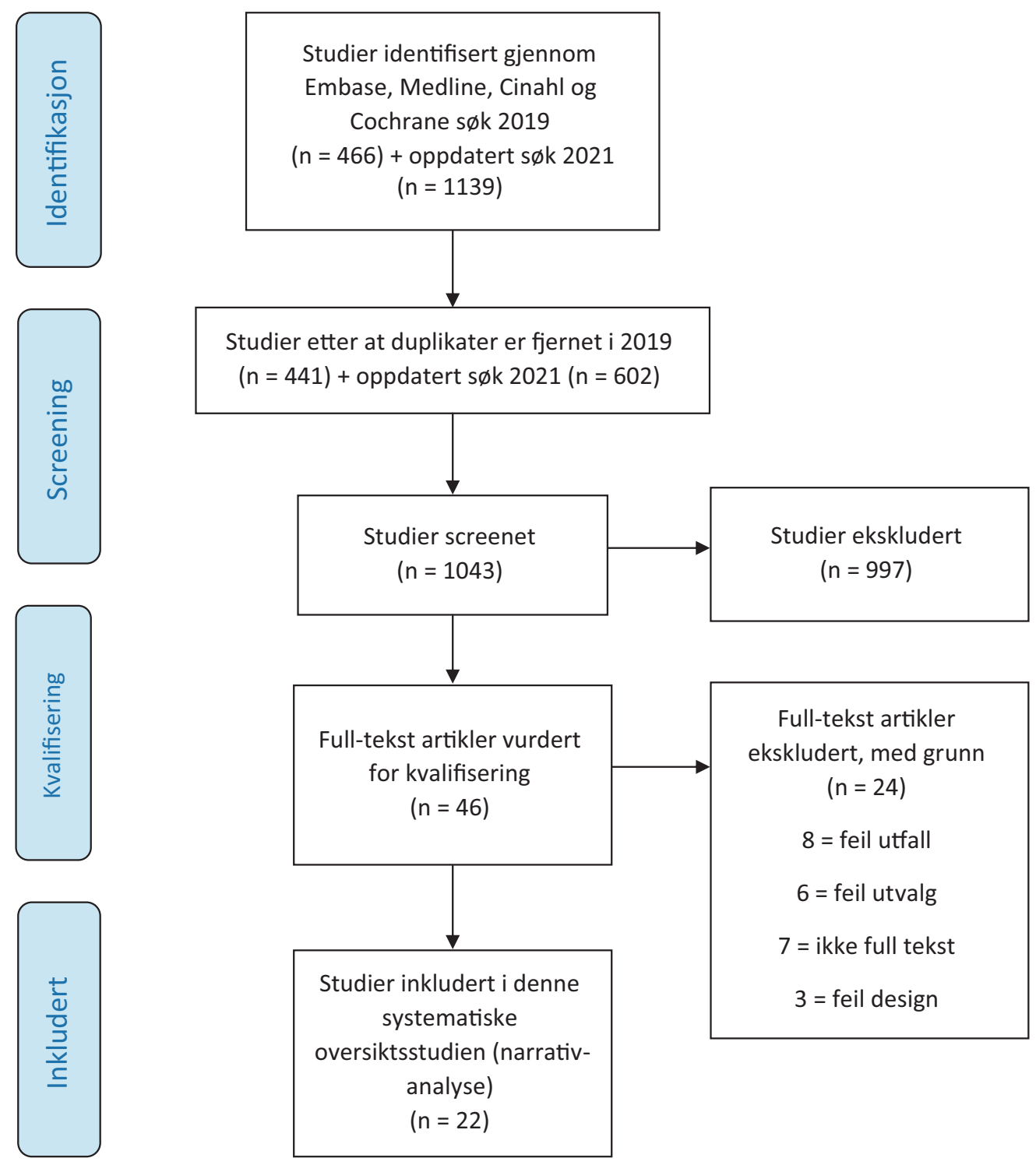

Figur 1 PRISMA flytdiagram av inkluderte studier (11) 


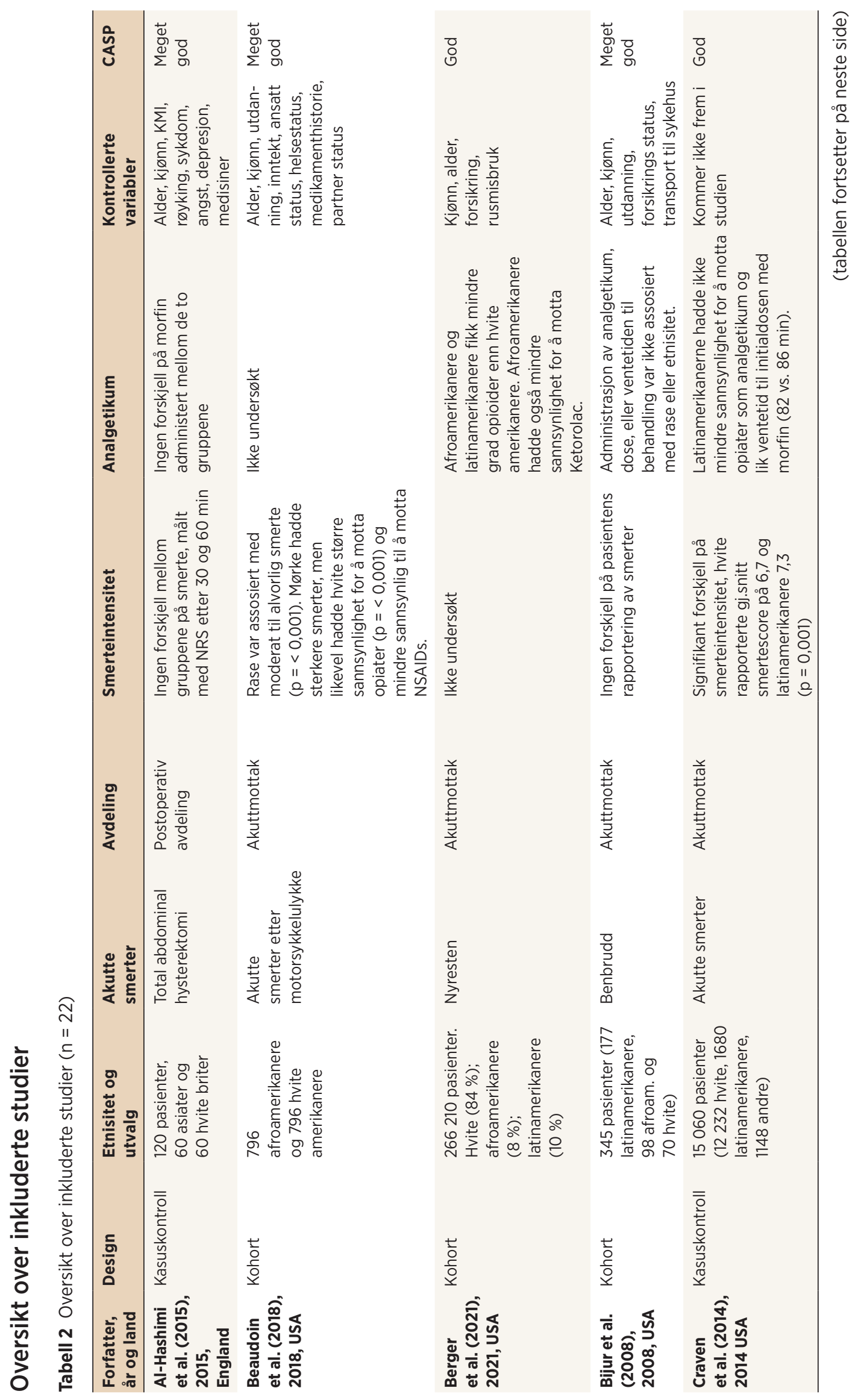




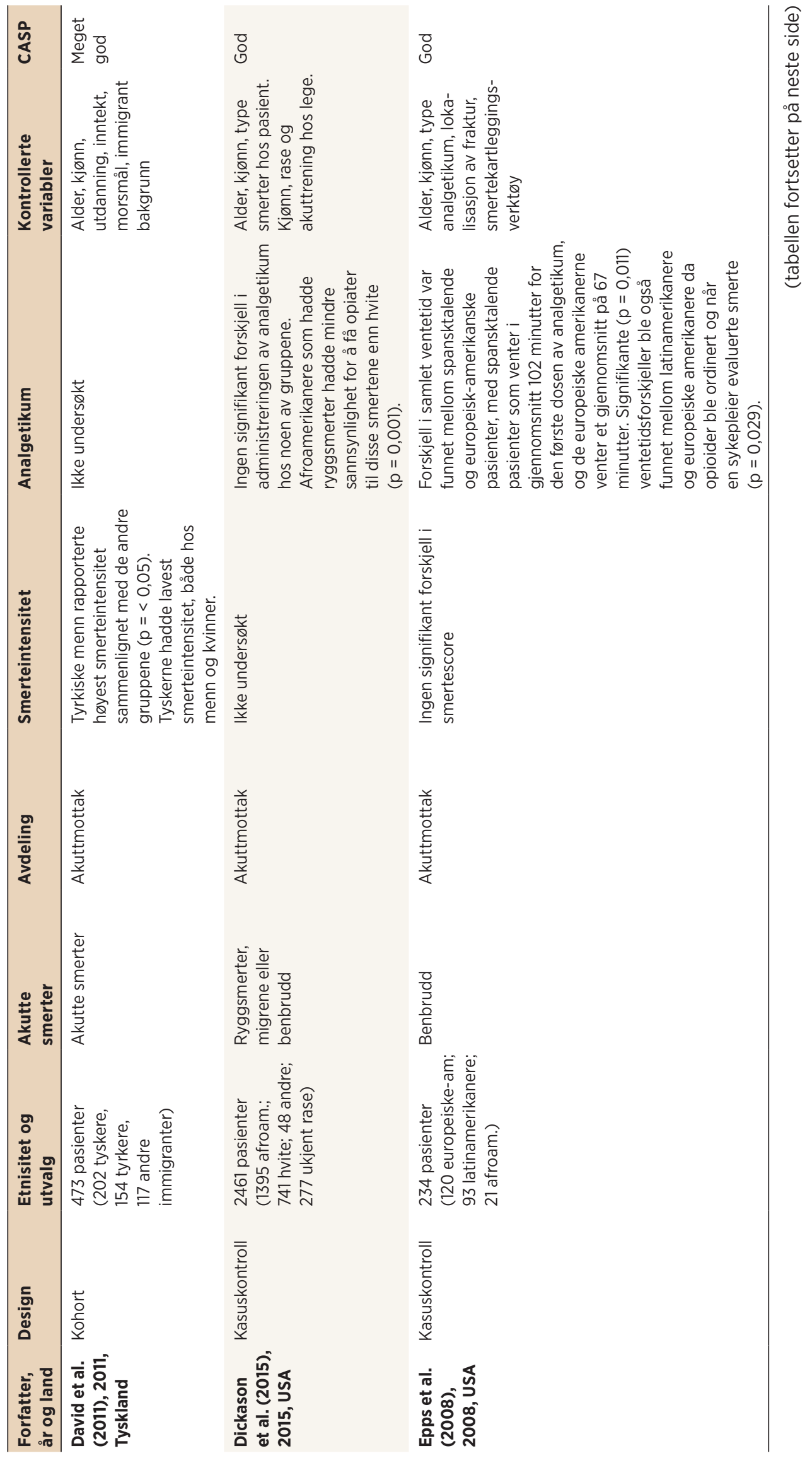




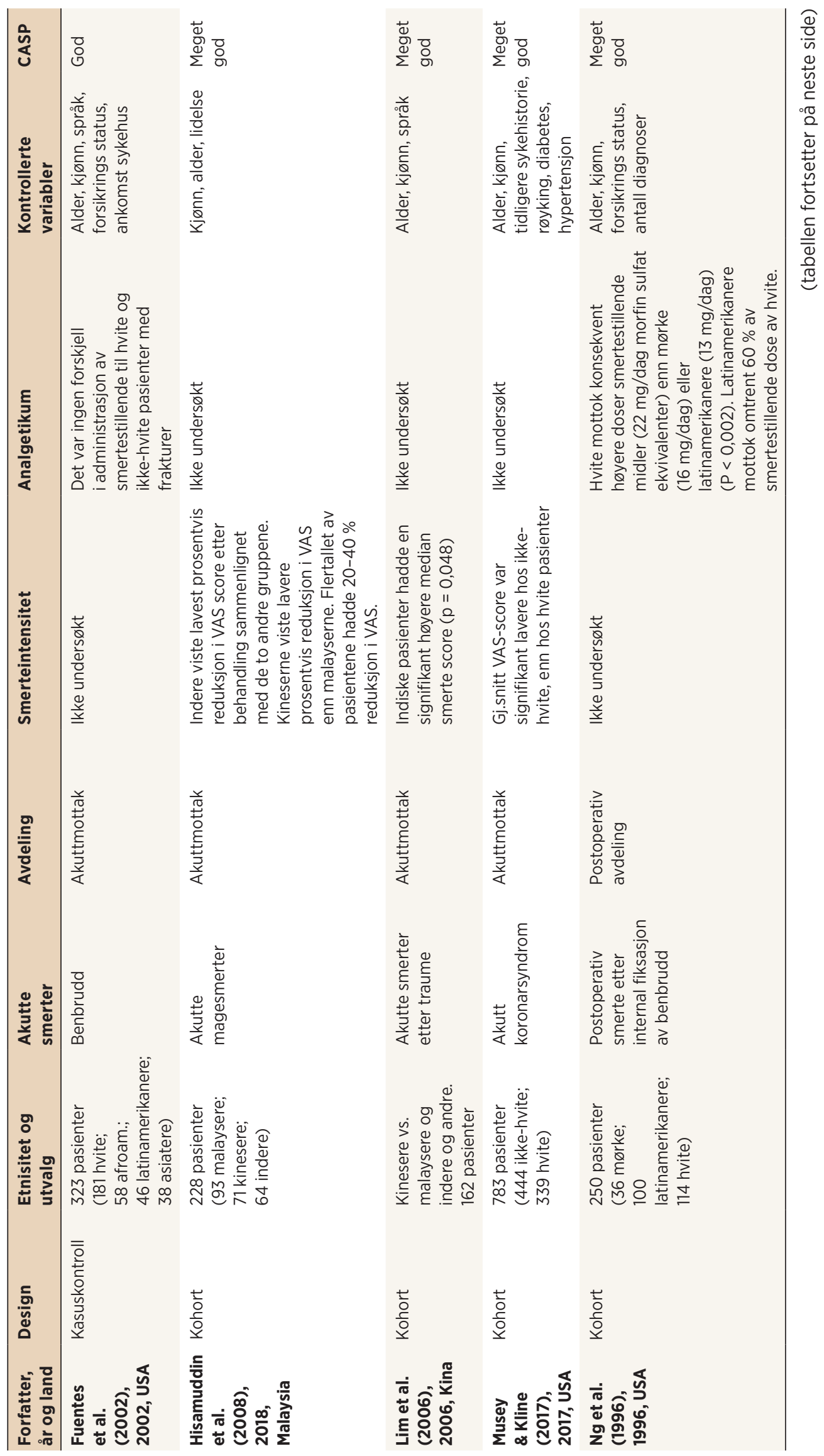




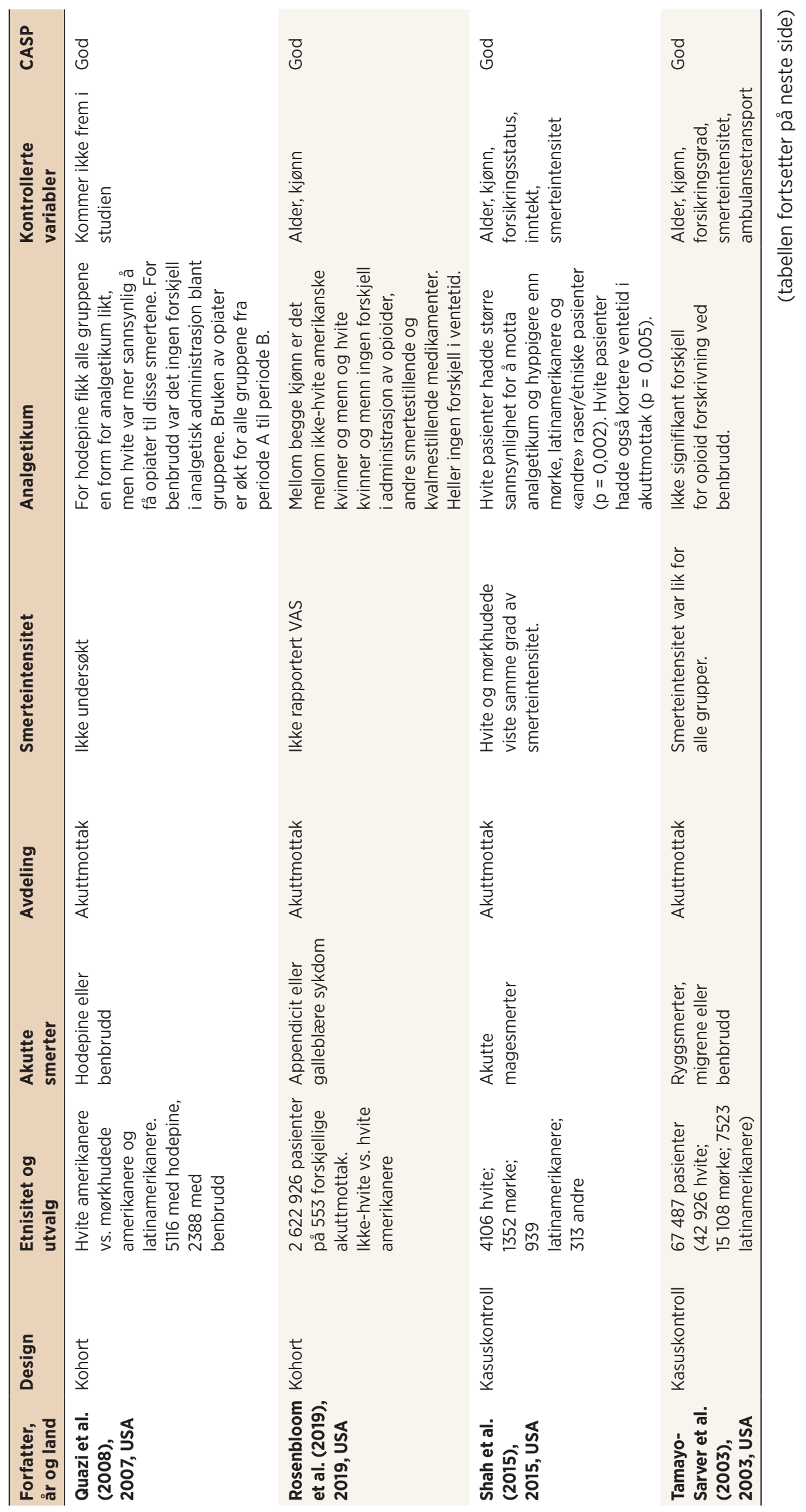




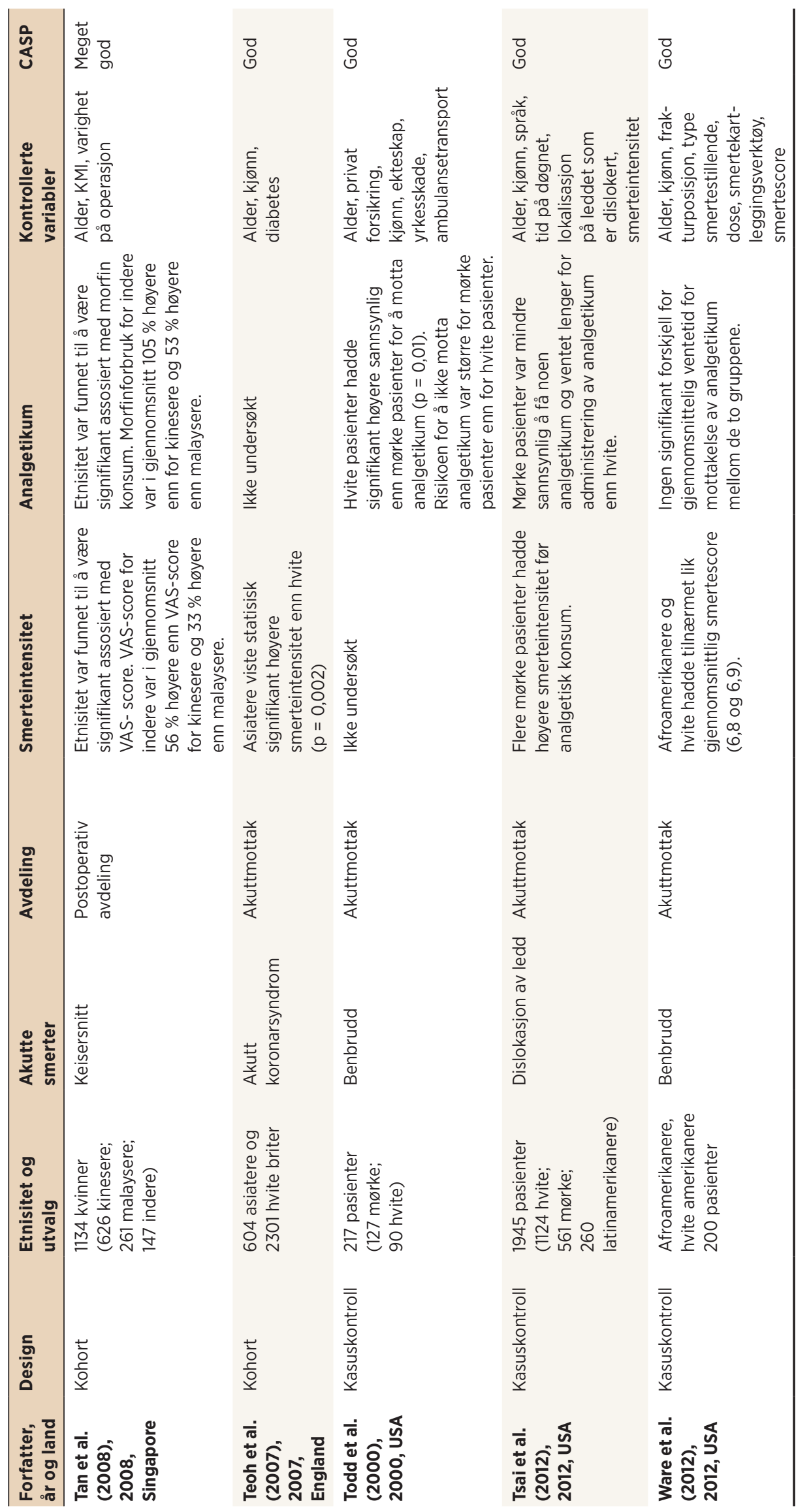


Tabell 3 Sammenfatning av resultat fra inkluderte studier

\begin{tabular}{ccccc}
\hline $\begin{array}{c}\text { Forskjell } \mathbf{i} \\
\text { smerteintensitet }\end{array}$ & $\begin{array}{c}\text { Forskjell } \boldsymbol{i} \text { valg av } \\
\text { analgetika }\end{array}$ & $\begin{array}{c}\text { Forskjell } \boldsymbol{i} \text { dose } \\
\text { og/eller frekvens }\end{array}$ & $\begin{array}{c}\text { Forskjell } \\
\text { i ventetid }\end{array}$ & $\begin{array}{c}\text { Ingen } \\
\text { forskjell }\end{array}$ \\
\hline $\begin{array}{c}(15,17,22,27,32, \\
34-37)\end{array}$ & $\begin{array}{c}(15,18,23,24,26, \\
27,30)\end{array}$ & $(19,24,27,30,37)$ & $(20,24,27)$ & $\begin{array}{c}(16,21,25,28, \\
29,31)\end{array}$ \\
\hline
\end{tabular}

\section{Forskjell i smerteintensitet og etnisitet}

I de inkluderte studiene var det flere studier som viste forskjell i smerteintensitet. Musey og Kline (2017) viste i sin studie at gjennomsnitt VAS-score var signifikant lavere hos ikke-hvite, enn hos hvite pasienter (22). Teoh et al. (2007) viser også forskjell i smerteintensitet ved at asiatene hadde signifikant høyere smerteintensitet enn hvite briter (32). Også Craven et al. (2014) fant i sin studie at hvite amerikanere hadde signifikant lavere smertescore sammenlignet med latinamerikanere (17).

En studie sammenligner tyskere med tyrkiske immigranter og andre immigranter. Denne studien ble utført ved tre store akuttmottak for gynekologi/indremedisin i VestBerlin. De fant at tyrkiske menn rapporterte høyest smerteintensitet sammenlignet med de andre gruppene før analgetika ble administrert. Tyskerne hadde lavest smerteintensitet, både hos menn og kvinner (36).

Tre studier sammenligner kinesere, malaysiere og indere. Den første studien konkluderte med at indere viste lavest prosentvis reduksjon i VAS etter analgetika sammenlignet med de to andre gruppene. Kineserne viste lavere prosentvis reduksjon i VAS enn malaysierne. Det vil si at malaysierne hadde best effekt av smertestillende, mens indere hadde høyest smerteintensitet både før og etter analgetika var administrert (35). Den andre studien kan vise til at indiske pasienter hadde en signifikant høyere smertescore enn malaysiere og kinesere (34). Den tredje studien ble utført i Singapore på en postoperativ avdeling, der forskerne fant ut at VAS-score for indere var i gjennomsnitt $56 \%$ høyere enn VAS-score for kinesere og $33 \%$ høyere enn malaysiere (37). Ut ifra disse tre studiene kan man si at indere scorer smerte høyere ved akutte smerter både før og etter analgetika er gitt enn malaysiere og kinesere.

\section{Forskjell i valg av analgetika, ventetid, dose og/eller frekvens}

I de inkluderte studier er det noen studier som viser forskjell i valg av analgetika, ventetid, dose og/eller frekvens på analgetika. I Shah et al. (2015) sin studie fant forskerne at hvite pasienter hadde større sannsynlighet for å motta analgetikum, samt motta analgetikum hyppigere enn mørke amerikanere og latinamerikanere. Hvite pasienter hadde også kortere ventetid til å motta analgetika i akuttmottak (24). Dette kan bekreftes av lignende studier $(19,20,26,27)$. Fem studier som er inkluderte i denne systematiske oversikten viser signifikante forskjeller i både smerteintensitet, ventetid til analgetika, administrert dose og medikamentvalg.

Dickason et al. (2015) kunne ikke vise til noen forskjell i administreringen av analgetikum til noen av gruppene, men afroamerikanere hadde mindre sannsynlighet for å 
få opioider for ryggsmerter enn hvite. Det viser Beaudoin et al. (2018) i sin studie også. Mørke amerikanere hadde større smerter, men likevel hadde hvite amerikanere større sannsynlighet for å motta opioider og mindre sannsynlighet for å motta nonsteroid anti-inflammatory drugs (NSAIDs) for smertene. I Quazi et al. (2008) sin studie hadde hvite større sannsynlighet for å få opioider for akutte smerter enn de andre etniske gruppene (23). Tan et al. (2008) viser at etnisitet var signifikant assosiert med morfinkonsum. Morfinforbruk for indere var i gjennomsnitt $105 \%$ høyere enn for kinesere og $53 \%$ høyere enn malaysiere (37). Disse studiene viser at etnisitet er assosiert med medikamentvalg.

\section{Ingen forskjell i smerteintensitet eller smertebehandling}

Noen av de inkluderte studiene viser ingen forskjell i smerteintensitet eller smertebehandling. Tamayo-Sarver et al. (2003) kunne ikke vise signifikant forskjell for opioidforeskrivning mellom hvite amerikanere, mørke amerikanere og latinamerikanere ved benbrudd. Smerteintensiteten var lik for alle grupper (25). Det er flere mindre studier som kan vise til lignende resultater $(16,21,28)$. Disse studiene kunne ikke vise til noen etniske forskjeller for smerteintensitet, valg av analgetika, dose eller ventetid for analgetika. Al-Hashimi et al. (2015) kunne heller ikke vise forskjell for postoperativ smerteintensitet, morfinbehov, smertehåndtering, bivirkninger eller varighet av liggetid postoperativt mellom sør-asiatere og hvite britiske pasienter (31).

\section{Drefting}

Det systematiske søket identifiserte 1605 artikler, hvorav 22 ble inkludert. Funnene fra denne studien tyder på at det forekommer uheldig forskjellsbehandling i vurdering og håndtering av akutte smerter i sykehus som kan begrunnes ut fra pasientens etnisitet. Alle pasienter har lik rett til behandling uavhengig av etnisitet, rase eller kultur (38).

Gjennom en systematisk innhenting av artikler fant vi at afroamerikanere scorer høyere på smerteintensitet sammenlignet med hvite; likevel har afroamerikanere mindre sannsynlighet til å motta opioider for smertene (15,19,20,22-24,26,27,30). Det samme gjelder latinamerikanere sammenlignet med hvite amerikanere (19,20,23,24,27). Er det noe med smerteuttrykket som helsepersonellet misforstår? I møte med pasienter tar også helsepersonellet med sin kulturelle bakgrunn i bedømming av smerter. De etniske forskjellene kan ifølge Ramer et al. (1999) forklares ved at kulturell bakgrunn bestemmer hvordan smerte oppleves, gir mening, hvordan og om en person kommuniserer smerten, eller synliggjør smerten, og hvordan personen håndterer og responderer på smerten (10). Meningen bak smerten og lidelsen kan være veldig forskjellig for de ulike kulturene. Det er helsepersonellets tolkning og vurdering av smerter som avgjør hvilken smertebehandling pasienten vil motta. Siden smerte ikke kan leses av på en monitor slik som puls og blodtrykk, blir pasientens kommunikasjon av smerte, pasientens smerteuttrykk det som betyr noe. Det er viktig å huske at annerledes ikke betyr unormal (1). 
Det er ikke sikkert smertekartleggingsverktøyene som er valgt passer til andre etnisiteter, dette gjelder spesielt hvis språket er dårlig. Kun et fåtall av studiene $(21,27,34,36)$ tar hensyn til morsmål/språk. Noen av studiene har tatt hensyn til språkbarrierer og derfor tatt i bruk tolk. Hvis det er en språkbarriere mellom pasient og helsepersonell vil det vanskeliggjøre evaluering av smerter. Pasientrettighetsloven (39) sier at «Informasjonen skal være tilpasset mottakerens individuelle forutsetninger, som alder, modenhet, erfaring og kultur- og språkbakgrunn». Det vil si at hvis det er en språkbarriere mellom pasient og helsepersonell må helsepersonell i henhold til norsk lov tilpasse informasjonen som gis, for eksempel ved bruk av kompetent tolk. Uten tolk er det umulig å adekvat bedømme smerte og lære bort smertehåndteringsprinsipper og forklare årsaken til smerten til en pasient som ikke snakker norsk. Dette kan medføre at smertekartleggingsverktøy blir misforstått, og at smerter kan bli over- eller underrapportert. Ikke-verbale kommunikasjonsmønstre kan variere like mye som verbal kommunikasjon mellom kulturer og gir derfor dårlig grunnlag for tolkning av smerter (9). Under visse omstendigheter kan observasjoner av adferd i målinger av smerte være et godt alternativ til numeriske selvrapporterings verktøy (som VAS og NRS), ettersom slike observasjoner kan bidra til å danne et bedre bilde av pasientens smerteopplevelse (4).

Tan et al. (2008) sammenlignet kvinner på postoperativ avdeling, og skriver at smerteintensitet og analgetisk praksis mellom malaysiere, kinesere og indere viser at indere scorer høyere på smerteintensitet ved akutte smerter og får hyppigere og høyere doser med opioider enn de andre gruppene (33). Dette er interessant, fordi i motsetning til de amerikanske studiene som sammenlignet afroamerikanere med hvite amerikanere og latinamerikanere, så får inderne mer opioider, men likevel scorer de høyere på smerteintensitet. Dette viser at smertebehandlingen i disse studiene ikke kan relateres til helsepersonellets underbehandling av smerter, men heller at indere har høyere smertesensitivitet ved akutte smerter.

Resultatene mellom inkluderte studier spriker noe. Flere mulige faktorer kan være årsaker til variasjonen i resultatene. Noen av studiene tar ikke høyde for variabler som kan påvirke smerte: alder, kjønn, smertekartleggingsverktøy, språk, etnisitet til pasient er dokumentert av sykepleier ikke av pasient, skiller ikke på rase/etnisitet og ikke nevnt hvordan data ble innsamlet. Dette kan ha bidratt til skjevheter. To av studiene $(17,23)$ har ikke kontrollert variabler som alder og kjønn. Det er mulig at etniske forskjeller er mer utbredt blant kvinner med forskjellig etnisitet enn hos menn eller omvendt. Studiene skriver ikke noe om utdanningsnivå eller tittel til dem som har evaluert og behandlet smertene til pasientene, forskerne refererer kun til at det er helsepersonell som har vurdert og behandlet smertene til pasientene.

Seks studier tar hensyn til forsikringsstatus (16,19,21,24-26). Helseforsikring er normalt ikke noe problem i Norge, men i utlandet og spesielt i USA kan dette være et stort problem hos minoriteter. Minoriteter har mindre sannsynlighet for å ha adekvat helseforsikring, som vil føre til begrenset helsetilbud og smertebehandling. Hvordan en pasient uttrykker smerte kan ofte forstås godt av de personer i samme kultur, men ikke så 
godt av dem utenfor kulturen (10). Ifølge Ramer et al. (1999) kan pasienter oppleve å ha lite kontroll over sin egen situasjon på sykehuset. For å oppnå smertekontroll, må pasienter føle at de aktivt er med å bestemme over sin egen smertebehandling (10). Det å lære pasientene å aktivt delta i behandlingen, øker følelsen av kontroll og dermed hvordan de håndterer smerten. Etniske minoriteter og individer med $\varnothing$ konomiske utfordringer kan ha vanskeligheter med å oppnå følelsen av kontroll i en setting dominert av velutdannede anestesi- og intensivsykepleiere. Hvilke forventninger den enkelte har til norsk helsevesen er et produkt både av individuelle og kulturelle faktorer. Enkelte er vant med og forventer at helsepersonell er autoritære og dikterer tiltak. Pasienten kan da ta rollen som mottaker i denne settingen og ikke klare å uttrykke sitt behov for å oppnå smertekontroll (10).

Mange av de amerikanske studiene skiller ikke mellom rase og etnisitet. Pasientenes etnisitet er ikke ordentlig beskrevet, og det er heller ikke tydelig beskrevet hvem eller hva som avgjør etnisiteten til pasienten, om det er selvrapportert eller om det er helsepersonellet som har bestemt etnisitet ut fra det de tror er riktig etnisitet. Konsekvensen av dette er at leseren ikke er sikker på hvilken kulturell bakgrunn pasientene i studiene har. I mange av studiene snakker de om etnisitet, men utvalget består av hvite, mørke og latinamerikanere. Eksempelvis kan latinamerikanere komme fra 19 forskjellige land (40), alle med sin egen sosiokulturelle historie. Det står heller ikke om pasientene er nylig immigrert eller om det er snakk om andre- eller tredjegenerasjons immigranter. Mørkhudede amerikanere er en annen rase enn de hvite amerikanerne, men forskerne bør ikke blande etnisitet og rase i samme forskning, da etnisitet er mye mer enn de fysiske egenskapene (8). En studie på raseforskjeller indikerer at det er biologiske forskjeller i smerte, eller at det kan være rasistiske holdninger hos helsepersonell til analgetisk administrasjon. Etniske forskjeller derimot kan handle om kulturforskjeller og smerteuttrykk som misforstås (1).

\section{Styrker og svakheter i studien}

Inklusjonskriteriene i denne systematiske oversikten var ganske smalt, fordi den tok kun for seg akutte smerter hos pasienter innlagt på en akuttavdeling på sykehus. Vi valgte å søke på generelle akutte smerter og ikke smerter fra et bestemt organ, derfor har vi inkludert studier som ser på akutte ryggsmerter, nyresten, benbrudd, keisersnitt, appendicitt, galleblære og koronarsmerter. Vi er klar over at smerter kan endre karakteristikk ut ifra hvilket organ som er affisert. Hvis et bredere spekter av smerte hadde vært inkludert, det vil si kroniske smerter, kreftsmerter og fødsels-/postpartumsmerter, ville det medført flere studier. På den annen side ble det tatt et valg om å ha en så smal søkestrategi som mulig for å få en spesifikk og relevant oversikt til anestesiog intensivsykepleie. At forskerne utførte en blindet screening av de inkluderte studiene er en styrke for denne systematiske oversiktsartikkelen. Begrep som kultur kunne blitt brukt fremfor etnisitet, det hadde kanskje gitt flere kulturspesifikke treff på studier om smerte. De fleste studiene er utført i USA, men likevel regnes resultatene som 
overførbare til norsk helsevesen, da vestlige land politisk og ideologisk er relativt like i sine holdninger til fremmede kulturer.

\section{Konklusjon}

Denne systematiske oversikten kan vise til at det er forskjeller for hvordan pasienter med ulike etnisiteter opplever akutte smerter og hvilken smertebehandling de mottar. $73 \%$ av de inkluderte studiene viser forskjeller i smertescore, og/eller studiene viser at det er forskjell for hvordan helsepersonell behandler smerte: hvilket medikament som velges, ventetid for administrering av medikamentet og dosen som velges. Resultatene kan bidra til at norske anestesi- og intensivsykepleiere får en $\varnothing \mathrm{kt}$ bevissthet rundt smertehåndtering.

Det er behov for flere studier som evaluerer smerte hos forskjellige etniske grupper av samme aldersgruppe og/eller kjønn. Vi trenger videre forskning som tar hensyn til språkbarrierer, og ikke minst trenger vi forskning som prøver å forstå årsaken til kulturelle forskjeller. Det er også i vurderingen av tilgjengelig litteratur viktig å kjenne til forskerens etnisitet. Fremtidens forskning bør fokusere på smerte gjennom sosiokulturelle ulikheter, denne systematiske oversikten er en viktig bidragsyter for kunnskap om temaet.

\section{Referanser}

1. Bjørkli AK. Ulike kulturer har forskjellige smerteuttrykk. Sykepleien. 2019;107. https://doi.org/10.4220/ Sykepleiens.2019.76013.

2. Devlin J, Skrobik Y, Gélinas C, Needham D, Slooter A, Pandharipande P, et al. Clinical practice guidelines for the prevention and management of pain, agitation/sedation, delirium, immobility, and sleep disruption in adult patients in the ICU. Crit Care Med. 2018;46(9):825-73. https://doi.org/ 10.1097/CCM.0000000000003299.

3. Gulbrandsen T. Smertelindring. I: Gulbrandsen T, Stubberud DG, red. Intensivsykepleie. Oslo: Akribe; 2005. s. 180-99.

4. Melzack R, Katz J. Pain measurement in adult patients. I: MacMahon SB, Koltzenburg M, Tracey I, Turk DC, red. Wall and Melzack's textbook of pain. 6 utg. Philadelphia: Saunders, Elsevier; 2013. S. 301-14.

5. Gelinas C. Pain assessment in the critically ill adult: recent evidence and new trends. Intens Crit Care Nurs. 2016(34):1-11. http://dx.doi.org/10.1016/j.iccn.2016.03.001.

6. Seymour B, Dolan R. Emotion, motivation and pain. I: MacMahon SB, Koltzenburg M, Tracey I, Turk DC, red. Wall and Melzack's textbook of pain. 6. utg. Philadelphia: Saunders, Elsevier; 2013.

7. Dhile A. Smerte og smertelindring. Anestesisykepleie. 3. utg. Oslo: Cappelen Damm; 2017.

8. Campbell C, Edwards R. Ethnic differences in pain and pain management. Future Medicine. 2012(2):219-30. https://doi.org/10.2217/pmt.12.7.

9. Narayan MC. Culture's effects on pain ass. and management. Am J Nurs. 2010;110:38-47. https://doi. org/10.1097/01.NAJ.0000370157.33223.6d.

10. Ramer L, Richardson J, Cohen M, Bedney C, Danley K, Judge E. Multimeasure pain assessment in an ethnically diverse group of patients with cancer. J Transcult Nurs. 1999(10):94-101. https://doi.org/ $10.1177 \% 2 \mathrm{~F} 104365969901000202$. 
11. Liberati A, Altman DG, Tetzlaff J, Mulrow C, Gøtzsche PC, Loannidis JPA, et al. The PRISMA statement for reporting systematic reviews and meta-analyses of studies that evaluate health care interventions: explanation and elaboration. Ann Intern Med. 2009;151(4):65-94. https://doi.org/ $10.1136 / \mathrm{bmj} . \mathrm{b} 2700$.

12. Ouzzani M, Hammady H, Fedorowicz Z, Elmagarmid A. Rayyan - a web and mobile app for systematic reviews. Syst Rev. 2016. https://doi.org/10.1186/s13643-016-0384-4.

13. Case Control Study Checklist 2021 [Internett]. Tilgjengelig fra: https://casp-uk.net/wp-content/ uploads/2018/03/CASP-Case-Control-Study-Checklist-2018_fillable_form.pdf [hentet 1. mai 2021].

14. Cohort Study Checklist 2021 [Internett]. Tilgjengelig fra: https://casp-uk.net/wp-content/uploads/ 2018/01/CASP-Cohort-Study-Checklist_2018.pdf [hentet 1. mai 2021].

15. Beaudoin FL, Gutman R, Zhai W, Merchant RC, Clark MA, Bollen KA, et al. Racial differences in presentations and predictors of acute pain after motor vehicle collision. Pain. 2018;159(6):1056-63. http://dx.doi.org/10.1097/j.pain.0000000000001186.0304-3959.

16. Bijur P, Berard A, Esses D, Calderon Y, Gallagher EJ. Race, ethnicity, and management of pain from long-bone fractures: A prospective study of two academic urban emergency departments. Acad Emerg Med. 2008;15(7):589-97. http://dx.doi.org/10.1111/j.1553-2712.2008.00149.x.

17. Craven P, Cinar O, Fosnocht D, Carey J, Carey A, Rogers L, et al. Prospective, 10-year evaluation of the impact of Hispanic ethnicity on pain management practices in the ED. Am J Emerg Med. 2014;32(9):1055-9. http://dx.doi.org/10.1016/j.ajem.2014.06.026.0735-6757.

18. Dickason M, Chauhan V, Mor A, Ibler E, Kuehnle S, Mahoney D, et al. Racial differences in opiate administration for pain relief at an academic emergency department. West J Emerg Med. 2015;16(3):372-80. http://dx.doi.org/10.5811/westjem.2015.3.23893.1936-900X.

19. Ng B, Dimsdale JE, Shragg GP, Deutsch R. Ethnic differences in analgesic consumption for postoperative pain. Psychosom Med. 1996;58(2):125-9. https://doi.org/10.1097/00006842-19960300000005 .

20. Epps CD, Ware LJ, Packard A. Ethnic wait time differences in analgesic administration in the emergency department. Pain Manag Nurs. 2008;9(1):26-32. https://doi.org/10.1016/j.pmn.2007.07.005.

21. Fuentes EF, Kohn MA, Neighbor ML. Lack of association between patient ethnicity or race and fracture analgesia. Acad Emerg Med. 2002;9(9):910-5. http://dx.doi.org/10.1197/aemj.9.9.910.

22. Musey PI, Kline JA. Do gender and race make a difference in acute coronary syndrome pretest probabilities in the emergency department? Acad Emerg Med. 2017;24(2):142-51. http://dx.doi.org/ 10.1111/acem.13131.1069-6563.

23. Quazi S, Eberhart M, Jacoby J, Heller M. Are racial disparities in ED analgesia improving? Evidence from a national database. Am J Emerg Med. 2008;26(4):462-4. http://dx.doi.org/10.1016/ j.ajem.2007.05.007.0735-6757.

24. Shah AA, Zogg CK, Zafar SN, Schneider EB, Cooper LA, Chapital AB, et al. Analgesic access for acute abdominal pain in the emergency department among racial/ethnic minority patients a nationwide examination. Med Care. 2015;53(12):1000-9. http://dx.doi.org/10.1097/MLR.0000000000000444. 0025-7079.

25. Tamayo-Sarver JH, Hinze SW, Cydulka RK, Baker DW. Racial and ethnic disparities in emergency department analgesic prescription. Am J Public Health. 2003;93(12):2067-73. https://doi.org/10.2105/ ajph.93.12.2067.

26. Todd KH, Deaton C, D’Adamo AP, Goe L. Ethnicity and analgesic practice. Ann Emerg Med. 2000;35(1):11-6. https://doi.org/10.1016/s0196-0644(00)70099-0.

27. Tsai CL, Sullivan AF, Gordon JA, Kaushal R, Magid DJ, Blumenthal D, et al. Racial/ethnic differences in emergency care for joint dislocation in 53 US EDs. Am J Emerg Med. 2012;30(9):1970-80. http://dx.doi.org/10.1016/j.ajem.2012.04.023.0735-6757. 
28. Ware LJ, Epps CD, Clark J, Chatterjee A. Do ethnic differences still exist in pain assessment and treatment in the emergency department? Pain Manag Nurs. 2012;13(4):94-201.

29. Rosenbloom JM, Burns SM, Kim E, August DA, Ortiz VE, Houle TT. Race/ethnicity and sex and opioid administration in the emergency room. Anesth Analg. 2019;128(5):1005-12.

30. Berger AJ, Wang Y, Rowe C, Chung B, Chang S, Haleblian G. Racial disparities in analgesic use amongst patients presenting to the emergency department for kidney stones in the United States. Am J Emerg Med. 2021;39:71-4. https://doi.org/10.1016/j.ajem.2020.01.017.

31. Al-Hashimi M, Scott S, Griffin-Teall N, Thompson J. Influence of ethnicity on the perception and treatment of early post-operative pain. Br J Pain. 2015;9(3):167-72. https://doi.org/10.1177/ 2049463714559254 .

32. Teoh M, Lalondrelle S, Roughton M, Grocott-Mason R, Dubrey SW. Acute coronary syndromes and their presentation in Asian and Caucasian patients in Britain. Heart. 2007;93(2):183-8. http://dx.doi. org/10.1136/hrt.2006.091900.1355-6037.

33. Tan EC, Lim Y, Teo YY, Goh R, Law HY, Sia AT. Ethnic differences in pain perception and patientcontrolled analgesia usage for postoperative pain. J Pain. 2008;9(9):849-55.

34. Lim GH, Wee FC, Seow E. Pain management in the emergency department. Hong Kong J Emerg Med. 2006;13(1):38-45. https://doi.org/10.1177\%2F102490790601300105.1024-9079.

35. Hisamuddin N, Kamaruddin J, Idzwan ZM, Rashidi A. Comparison of acute pain relief, after intravenous morphine administration, among different ethnic groups who presented with acute abdominal pain in the emergency department. J Emerg Med. 2008;8:73-7.

36. David M, Pant HA, Oligmuller AK, Babitsch B, Borde T. Ethnic differences in reported pain regions - results of a survey at three clinical emergency rooms in Berlin/Germany. Geburtshilfe und Frauenheilkunde. 2011;71(1):44-52. http://dx.doi.org/10.1055/s-0030-1250722.0016-5751.

37. Tan CE, Lim GH, Teo YY, Goh KJ, Law HY, Sia AT. Ethnic differences in pain perception and patientcontrolled analgesia usage for postoperative pain. J Pain. 2008;9(9):849-55. https://doi.org/ 10.1016/j.jpain.2008.04.004.

38. Lov av 24.06.2011 § 2-1 b. Lov om pasient- og brukerrettigheter (Pasient- og brukerrettighetsloven). Tilgjengelig fra: https://lovdata.no/dokument/NL/lov/1999-07-02-63\#KAPITTEL_2 [hentet 28.05.2021].

39. Lov av 24.06.2011 §3-5 Lov om pasient- og brukerrettigheter (Pasient- og brukerrettighetsloven). Tilgjengelig fra: https://lovdata.no/dokument/NL/lov/1999-07-02-63?q=pasientrettighetsloven\#KAPIT TEL_3 [hentet 20.04.2021].

40. Countries in Latin America and the Caribbean: Worldometer; 2021 [Internett]. Tilgjengelig fra: https://www.worldometers.info/geography/how-many-countries-in-latin-america/ [hentet 20.04.2021]. 